\title{
Linking International Norms to Regions: Mercosur and ASEAN facing the challenge of cultural diversity
}

Antonios Vlassis'

\begin{abstract}
The Convention on diversity of cultural expressions (CDCE), adopted by UNESCO in 2005 , became a main mechanism within the multilayered global governance of cultural industries, establishing new practices regarding the cultural sector. My article encourages an original view on norm diffusion and implementation focusing on two regions: Mercosur (Southern Common Market) and ASEAN (Association of the Southeast Asian Nations). Through the analysis of the CDCE's transfer from international level to Mercosur and ASEAN regions, my article seeks to explore four key questions: why do actors engage in norm transfer? Who are the key actors involved in the norm transfer process? What is transferred and why? What restricts or facilitates the norm transfer process?
\end{abstract}

Keywords: norm diffusion, regions, Mercosur, ASEAN, UNESCO, non-governmental organisations, cultural industries, cultural diversity.

During the 1990s, rapid financial globalization, international and regional economic integration, and the liberalization of trade exchanges raised major concerns for several actors over their effects on cultural policies, flows of cultural goods and services, and cultural diversity. By the end of 1990s, a transnational advocacy network - composed of several national governments, such as France and Canada, of international organizations, such as Organisation internationale de la Francophonie (OIF) and Council of Europe, culture organizations of professionals as well as experts - has been established in favour of the diversity of cultural expressions and of the

1 Researcher and Lecturer, Fonds national de la Recherche Scientifique (FNRS)-Center for International Relations Studies (CEFIR), University of Liege, Belgium. E-mail: antonios.vlassis@gmail.com. 
adoption of an international policy tool on this principle. A main goal of this network was the construction and acceptance of a specific problem such as the threat of free trade agreements (FTAs) on cultural policies ${ }^{2}$ as international issue (VLASSIS, 2015a).

Following hard negotiations on several issues such as FTAs and culture, appropriate cultural policies for the diversity of cultural expressions, or the contributions for a fund for cultural diversity, a new standard-setting instrument -the Convention on the Protection and the Promotion of Diversity of Cultural Expressions (CDCE) - was adopted by UNESCO in 2005. As of January 2017 it has received the support of 144 States and of the European Union (EU). The CDCE, entered into force in 2007, recognizes the specificity of cultural goods and services and the importance of cultural policy for the protection and promotion of the diversity of cultural expressions (VLASSIS, 2011). The CDCE also acknowledges the role of civil society for the protection and promotion of diversity of cultural expressions (Article 11) and it stipulates the integration of cultural industries in sustainable development policies (Article 13). Furthermore, it aims to strengthen international cultural cooperation through various tools, such as the expert and information exchange among the Parties (articles 9 and 19), the collaborative arrangements (article 15), the preferential treatment for developing countries (Article 16) as well as the setting up of the International Fund for Cultural Diversity (IFCD), a multidonor voluntary Fund established under Article 18 (ALBORNOZ, 2015).

The CDCE became a main mechanism within the multilayered global governance of cultural industries ${ }^{3}$,challenging the scope of bilateral and

2 One of the initial issues of the global governance of cultural industries deals with the treatment of the cultural and audiovisual goods and services within FTAs. In the 1990s, the US administration pushed for further liberalization of audiovisual services on one side, and on the other a competing coalition of actors, driven by France and Canada, defended the term of cultural exception in order to recognize the legitimacy of cultural policies. The objective was to exclude cultural and audiovisual goods and services from the agenda of international negotiations on FTAs such as the last period of negotiations on the General Agreement on Trade in Services of the World Trade Organization (WTO) in 1993, the negotiations on Multilateral Agreement on Investment within the Organization for Economic Cooperation and Development, as well as the negotiations on the FTA between the US and Canada (1989) and on the North American FTA (1994) between the US, Canada and Mexico.

3 By multilayered global governance, I mean a system composed of norms, rules and institutions, affecting several aspects of cultural goods and services (creation, production, distribution, exhibition) and allowing the involved actors to coordinate their practices in a context of disaggregated sovereignty, of polyarchic authority and of absence of global government (AVANT et al., 20/0). 
multilateral trade agreements and establishing new practices regarding the link 'culture and development'. A recently growing body of academic research examines numerous aspects of the CDCE building and implementation, offering useful insights on the legal features of the implementation (RICHIERI HANANIA, 2014; BURRI 2014), the links between CDCE and trade agreements (NEUWIRTH, 2013; SHI, 2013; GAGNE, 2016), the contribution of the CDCE to the development strategies (DE BEUKELAER et al. 2015; VLASSIS 2015b), as well as the role of UNESCO (VLASSIS 2013; KOZYMKA 2014) and of the EU (LOISEN and DE VILLE, 2011; VLASSIS 2016a) as regards the CDCE implementation. However, recent research has not sufficiently explored the links between international and regional levels, the impact of the CDCE on regions, as well as on how governments of different regions translate the CDCE normative framework (see VLASSIS, 2016b).

On one hand, national governments and regional organizations learn from beyond their borders. In this respect, the inclusion of new policy principles and the change of national and regional agendas in a variety of areas depend on it. On the other hand, disseminating and implementing international norms is "almost always a contested process" requiring actors to exercise "a great deal of discretion and autonomy to translate them into action" (AVANT et al., 2010, p. 15). My article encourages an original view on normdiffusion focusing on two regions: Mercosur (Southern Common Market) and ASEAN (Association of the Southeast Asian Nations). "Regions are now everywhere across the globe and increasingly fundamental to the functioning of all aspects of world affairs" (FAWN, 2009, p. 5).I may assume that there are twomain ways through which regional spaces and organizations relate to international norms (NESADURAI, 2005, p. 158): first, the international norms may be reproduced at the ASEAN and Mercosur levels. In that sense, regions and international norms are mutually reinforcing; a second way could see ASEAN and Mercosur as a form of resistance to international norms and as spaces and entities, which disseminate alternate norms, ideas and practices to those that predominate at the international level.

In fact, through the socio-political analysis of the CDCE's transferfrom international level toMercosur and ASEAN regions, my article seeks to explore fourkey questions: why do actors engage in norm transfer? Who are 
the key actors involved in the norm transfer process? What is transferred and why? What restricts or facilitates the norm transfer process? (DOLOWITZ and MARSH, 2000, p. 8). Furthermore, it aims to advance debate about comparative regionalism, breaking out of "simply celebrating differences between European integration and regionalism in the rest of the world" (SÖDERBAUM, 2016, p. 69).

Based on document analysis and on four semi-structured interviews with actors involved, the article will address this issue in two steps: first, it highlights the role of these regions in the CDCE implementation, the effects of the CDCE on the Mercosur and ASEAN states, as well as on the policy agenda of the two regional organizations. Second, it attempts to understand the factors, which contribute to the CDCE transfer process, to focus on the key drivers of this process, to emphasize the conditions in which international norms are supposed to make a difference, as well as the competing ideas that the CDCE face in these regions, and especially in ASEAN.

\section{The diversity of cultural expressionsin ASEAN and Mercosur regions}

\section{Mercosur states as key players of the CDCE implementation}

The CDCE is at the heart of the policy agenda of all the Mercosur states ${ }^{4}$. The latters are already Parties to the CDCE: Brazil and Uruguay since January 2007, Paraguay since October 2007, Argentina since May 2008, and Venezuela since May 2013.Even though the Mercosur did not participate as a single entity during the negotiations leading to the CDCE such as the EU, the Mercosur states had a common agenda, which consisted of favouring the inclusion of culture in development policies (UNESCO, 2004). Besides, whereas the interface 'trade-culture' was not a key issue for the Mercosur delegations during the negotiations, it's noteworthy that the Mercosur states have a coherent position within the WTO and it did not take commitments

4 The Asuncion Treaty is the fundamental treaty of Mercosur signed between Argentina, Brazil, Paraguay and Uruguay in 1991 for establishing a common regional market. A first step to reinforce the Mercosur countries cooperation in the cultural domain has been the "Mercosur Protocol of Cultural Integration" signed in 1996 in Fortaleza. 
on the audiovisual sector.In December 2005, the CDCE became even a high-politics issue during the $29^{\text {th }}$ Summit of Presidents of Mercosur and of associated states with a common statement with reference to the importance of the CDCE adoption and to the fact that "culture, because of its special nature, is not simply a product".

Regarding the CDCE implementation, each Party submits the fourth year following the year in which it ratifies the CDCE a quadrennial report, including information on policies adopted by the Party for the diversity of cultural expressions at both the national and the international levels. Argentina, Brazil, Uruguay and Paraguay submitted their report in 2012, whereas Venezuela is supposed to provide its report in 2017. According to UNESCO's experts, eight innovative policy practices have been identified in the Mercosur region, dealing with culture and sustainable development, digital technologies, international cooperation, public service broadcasting or participation of civil society:

- Argentina's Cultural Industries Skills Training launched in 2009 providing training to over 1500 young people;

- Uruguay's National Youth Plan 2011-2015, which integrates culture among its strategic action lines;

- the Argentine Cultural Industries Market held in 2011;

- the policies related to transforming Buenos Aires into a global hub for the production of Spanish-language audiovisual content for children $^{5}$;

- the ministry of Education and Culture Centres in Uruguay built up in 2007;

- Brazil's international audio-visual cooperation policy for encouraging international co-productions and promoting Brazilian films in the international audiovisual market;

5 The Argentinian Government adopted in 2010 legislation requiring television to broadcast three hours of content for children a day, of which 50\% must be domestically produced. In this respect, Buenos Aires received technical resources within the framework of the UNESCO-CDCE expert facility project in order to create a viable audiovisual content sector for children. 
- Paraguay's National Council of Culture established in 2010 including, along with central and local governmental actors, representatives of various cultural sectors and industries;

- Promotion of the CDCE among civil society in Brazil through the organization of a series of workshops on cultural policies for artists and cultural professionals and entrepreneurs.

Furthermore, to the present date, Mercosur states are strongly involved in the implementation of the IFCD, revealing an effective partnership between national authorities and civil society in the cultural sector. In total, eight projects from Mercosur states have been funded by the IFCD with a total allocation of 690.000 USD.

Brazil - both an important donor/receiver and a staunch supporter of multilateral practices - has contributed to the IFCD with 300.000 USD, whereas two Brazilian projects received resources from the fund: a project providing training to indigenous filmmakers (97.580 USD) and a project for empowering indigenous creators by promoting their participation in the digital publishing sector (90.950 USD). On its turn, Uruguay contributed once to the IFCD with 1.600 USD, but remains one of the most dynamic countries of Latin America in terms of allocation of IFCD resources. Three projects have been funded (260.000 USD in total) dealing with capacity and cultural industry development, as well as social development and culture: (i) Comparsa, encouraging social participation through music; (ii) Fostering cultural participation for poverty alleviation; (iii) Fostering an active participation of vulnerable groups in the creative sector in Uruguay. For their part, Argentina and Paraguay have no contribution to the IFCD but two projects from Argentina (158.000 USD in total) and one from Paraguay (90.000 USD) have been funded.Besides,Argentina has established in 2010 and 2011 a specific policy measure entitled 'Cultural diversity as development agent in Argentina' in order to promote and disseminate awareness of the CDCE. In doing so, three different workshops were organized.

To this picture it should be added the CDCE's impact in other ways too, embedded in technical discussions among Mercosur states. The Mercosur is a regional integration project that has reached "the greatest level of formal accomplishment after the EU" (MALAMUD and SCHMITTER, 2011, 
p. 135). Since early 2010, the Mercosur states have adopted the theme of cultural diversity within Mercosur Cultural ${ }^{6}$ and have made it a component of the Mercosur policy agenda. In this respect, in November 2012, the Mercosur Commission on Cultural Diversity has been established in Brasilia under the instigation both of Brazil and Argentina seen as the cellula mater of the organization (SANTANDER, 2012, p. 14). In total, four meetings of the Commission on Cultural Diversity were held so far. The participants have dealt with main topics: the articulation between cultural policies of Mercosur states and CDCE, as well as the inclusion of culture in the post2015 development agenda (see VLASSIS, 2015b). Besides, a Fund for the Mercosur cultural integration was created in 2010 and one of its objectives is to promote "the diversity of cultural expressions which contribute to the process of the integration". Moreover, in April 2012, within the framework of Cultural Mercosur and jointly with UNESCO, a conference was organized on "Reflexions on the Convention on the protection and promotion of the diversity of cultural expressions". Lastly, in 2014, Mercosur, under the instigation of Argentina, published the report La diversidad de las expresiones culturales: buenas practicas en el Mercosur.

\section{ASEAN region and CDCE: an instrument for strengthening policy capacity and expertise}

ASEAN gathers today ten member countries with diversified levels of economic development, and with very different political and social systems, as well as different cultural and religious values. Five countries officially formed the Association in 1967: Indonesia, Malaysia, the Philippines, Singapore and Thailand and Brunei joined in 1984. In the context of the end of the Cold War, Cambodia, Laos, Myanmar and Vietnam joined ASEAN between 1995 and 1999. As Katzenstein argued (2005, p. 141), ASEAN is "the only regional institution in Asia that has attracted strong political support".

Four ASEAN states are already Parties to the CDCE: Vietnam since August 2007, Cambodia since September 2007, Lao People's Democratic Republic since November 2007, and Indonesia since January 2012. By

6 The Ministers of Culture established the Mercosur Cultural in 1998 as an institutional mechanism for promoting the exchanges among the officials of Mercosur countries' ministries of Culture. 
contrast, Brunei, Singapore, Malaysia, Myanmar, Philippines, and Thailand are no Parties to the CDCE. It's interesting to point out that during the negotiations on the CDCE, the only ASEAN countries, which made specific comments on the content of the Convention's draft were Philippines, Thailand, and Vietnam. Whereas Vietnam followed notably the position of France and Canada, Philippines and Thailand expressed various criticisms: the latter regarding the broad and confusing scope of the Convention and the former about the importance of recognizing the cultural expressions of autochthonous people (UNESCO, 2004).

In this sense, the development assistance from the CDCE is concentrated on the new ASEAN members (Cambodia, Laos and Vietnam), as well as on Indonesia. In total, four projects have been funded by the IFCD with an allocation of 285.000 USD: Two projects from Cambodia on 'Young artists building Cambodia's future cultural industries' and on 'Building a sustainable performing arts industry in Cambodia', a project from Indonesia regarding the development of an audiovisual industry in Siberut, as well as a project from Laos regarding the organization of seminars on implementing the CDCE.

Instead, in order to understand the CDCE transfer it is necessary not only to see what transferred but also to consider the motivations involved (DOLOWITZ and MARSH, 2000, p. 6). In contrast to Mercosurstates, the four ASEAN countries sought largely to use the CDCE for improving and developing their technical capacity on cultural policies and cultural industries. Besides, it's revealing thateven though Vietnam, Cambodia and Laos ratified the CDCE in 2007, they have not provided their quadrennial report due to a lack of expertise, of technical capacity, and of understanding the CDCE's scope.

Subsequently, Vietnam, Cambodia and Indonesia received substantialtechnical resources within the UNESCO-CDCE expert facility project funded by the EU and Swedish Agency for International Development Cooperation. During the two phases of the project, five technical assistance missions have been put in place in the three countries. It's worth mentioning that on the one hand, since 2011 Cambodia has aimed to establish a policy framework on contemporary cultural industries and has elaborated a document entitled Cultural policy for Cambodia - initial proposal. In this respect, the two technical missions sought to strengthen the capacity building 
of the government. They aimed to develop priority actions and strategies under the new Cultural Policy and to strengthen human and institutional capacities of governmental and civil society actors to monitor and report on the diversity of cultural expressions, through preparation of quadrennial reports 7 . On the other hand, the two technical missions in Vietnam dealt with the development and implementation of the country's strategy on cultural and creative industries by 2020. In the same vein, the capacity building in Indonesia focused on the preparation of quadrennial reports.

\section{From international to regional: dynamics of spreading and learning}

Why do some international ideas find greater acceptance in a particular region than in another? (ACHARYA, 2004, p. 240). The challenge is to understand the different dynamics and multidimensional process through which the diversity of cultural expressions has been spread in Mercosur and ASEAN since early 2000s. In fact, the two regions experience external influences differently and they exercise different kinds of influence (KATZENSTEIN, 2005, p. 179). This section explores the mechanisms through which the CDCE is disseminated in the two regions, its effects on political behaviour, the failures of the norm diffusion, as well as the heterogeneity among state strategies and the competition among external actors. As a result, I identify different arrays of actors involving in ASEAN and Mercosur regions and different linkages between regional and external actors.

\section{Mercosur region: legitimacy from the bottom and strong socialization}

\section{International norms, national NGOs and transnational networks}

One of the main players of thetransnational network, which paid specific attention to the idea of adopting a standard setting instrument on diversity of cultural expressions, was the global movement of Coalitions for

7 In the framework of the Millennium Development Goals, Spain also supported the Creative Industries Support Programme in Cambodia with a financial aid of 3.2 millions USD. The programme has been established by UN agencies and local organizations. 
Cultural Diversity. The Coalition for Cultural Diversity was first established in 1998 by Quebec's culture professional associations.In September 2007, the International Federation of National Coalitions for Cultural Diversity (IFCCD) was created by 42 coalitions grouping more than 600 cultural professional organizations.

In Mercosurregion, the first Coalition for Cultural Diversity has been established in Argentina in 2002, followed by the Coalitions of Uruguay, of Brazil and of Paraguay created in 2004, 2005 and 2006 respectively. The professional associations in the cultural milieu arewell organized and played a significant role for introducing the issue of diversity of cultural expressions in the agenda of Mercosurstates. They represent developed cultural industries and they established strong links with the transnational advocacy network and the IFCCD more specifically.

In this sense, it should be noted that in September 2005 Argentina's Coalition hosted the seventh general assembly of the International Liaison Committee (ILC) of Coalitions for Cultural Diversity ${ }^{8}$ in Buenos Aires?. The meeting was organized with the financial support from the Canadian and French Coalitions and the Culture Secretariat of the City of Buenos Aires ${ }^{10}$. Besides, in September 2001, professional organisations of Argentina and Brazil participated at the First International Meeting of professional culture associations, held in Montreal, focusing on 'Cultural diversity, cultural policies and international trade agreements" .

Moreover, Brazil's role in the cultural diversity debate was one of the key themes of the Fifth Congress of Brazilian Cinema, in December 2003, bringing together 40 professional organizations from Brazil's cinema industry. A seminar was held on the convention on cultural diversity with the participation of representatives of Brazilian government, of Brazilian cinema

8 The International Liaison Committee was an informal network created in March 2003 for facilitating exchanges and cooperation among existing coalitions in the world. It was replaced in 2007 by the IFCCD.

9 The data included in this section is largely based on the newsletter of the Coalitions for Cultural Diversity entitled "Coalition currents", which has published since 2003

10 In parallel, the City of Buenos Aires hosted the third international meeting on cultural diversity and a meeting of the culture secretariats of the major Iberoamerican cities.

11 In total, the Meeting brought together 40 professional organisations coming from 10 countries: Argentina, Australia, Brazil, Chile, Republic of Korea, Denmark, Spain, France, Mexico, and Poland. 
organizations, as well as of Jim McKee of the Canadian Coalition speaking on behalf of theInternational Liaison Committee of Coalitions.

In the same vein, in June 2006, Robert Pilon - executive vice-president of Canadian Coalition for Cultural Diversity and spokesperson for the movement ofthe Coalitions - and Uruguay's Coalition for Cultural Diversity met several representatives of the national ministry of Foreign Affairs and of the Ministry of Education and Culture in order to discuss about the process of the CDCEratification and implementation. In July 2006, a delegation representing Ibero-American coalitions for cultural diversity transmitted a declaration on the CDCE adopted at the Fortaleza meeting of Coalitions to a meeting of ministers of culture of the Ibero-American States.

Importantly, the Coalitions played a role for linking the CDCE to national contexts. In January 2013 the Paraguayan Coalition for Cultural Diversity drew up a mixed report of governmental actions, included 18 recommendations, strongly inspired of the CDCE, such as awareness of cultural rights, the establishment of an advisory mechanism of the National Council of Culture or the design of a national plan for culture through a participatory process.

To this picture it should be added that several cultural policy experts and cultural practitioners from Mercosur region participated at the meetings organized by U40 Global Network "Cultural Diversity 2030", which aimed to involve young professionals in the CDCE implementation. The network was established in 2009 collaboratively by the German Commission for UNESCO and the IFCCD. In doing so, the first Interamerican U40 held in Montreal in May 2010 brought together 30 young professional from 11 North, Central and South American countries, whereas 43 cultural sector experts coming from 14 countries participated at the second Interamerican U40 meeting held in Toluca, Mexico in 2011. Each meeting produced specific proposals for the CDCE implementation at the local, national and regional levels.

Lastly, an Observatory for Cultural Diversity, under the initiative of several academics, began operations in 2005 in Salvador de Bahia, Brazil. It organizes the Cultural Diversity Seminar strongly related to the CDCE framework, with seven editions already concluded. 


\section{National policy-makers in regional spaces}

A wide range of multilateral meetings and venues isa valuable mechanism for learning about diversity of cultural expressions. It's important to mention four multilateral arenas, through which the diversity of cultural expressions has been spread: (i) the Inter-American Committee on Culture and the Inter-American Meetings of Ministers of Culture; (ii) the Assembly of the Parliamentary Confederation of the Americas (COPA) and the sessions of the Committee on Education, Culture, Science and Technology; (iii)the EU, Latin American and the Caribbean Summit; (iv) the Ibero-American Conferences on Culture.

First, the Seventh General Assembly of the COPA was held in Quito, Ecuador, in May 2006 under the theme 'Trade agreements and economic development'. In this context, Claude Boucher (2006), a member of the Quebec National Assembly presented a follow up report on hemispheric implementation of the CDCE and international trade negotiations. In parallel, the assembly adopted a recommendation on the CDCE's ratification. Besides, at the first work session of the Committee on Education, Culture, Science, and Technology held in Mexico in November 2002, members discussed the issue of cultural diversity, and most importantly, they called to refrain from committing to trade liberalization agreements affecting the cultural sector in negotiations concerning the creation of a Free Trade Area of the Americas. Lastly, the COPA General Assembly held in Foz do Iguaçu, Brazil, in May 2005 adopted also a recommendation on this issue.

Second, the protection of cultural public policies became a key topic within the inter-American exchanges of national authorities. It should mention three meetings. The First Interamerican meeting of Ministers of Culture took place in Cartagena de Indias, Colombia, in July 2002 sponsored by the Organization of American States (OAS). The Declaration and the Plan of Action of Cartagena focused on the multilateral cultural cooperation and reaffirmed the diversity of cultural expressions as one of the priorities of the inter-American cultural dialogue. The Declaration recognizes "the importance of cultural policies within public policies" and it stresses the "important work done by Canada as President of the Working Group on Culture and as coordinator of the First Hemispheric Experts Seminar on Cultural Diversity" 
(ORGANISATION OF AMERICAN STATES, 2002, p. 2-4). Following this, the first meeting of the Inter-American Committee on Culture held in 2003 and the Special Summit of the Americas in Monterrey in 2004 made explicit reference to the necessity of theCDCE's adoption.

Third, the declaration of the $4^{\text {th }}$ Summit between the EU, Latin America and the Caribbean (EULAC) held in Vienna, Austria, in May 2006 mentioned explicitly the importance of cultural diversity "as a factor of development, growth and stability, as illustrated by the adoption of the UNESCO CDCE in October 2005", supporting also "its prompt ratification and implementation" (EU-LAC, 2006, p. 16).

Lastly, the ninth Ibero-American Conference on Culture held in Montevideo, Uruguay, in July 2006, elaborated the 'Iberoamerican Cultural Charter'. The latter reaffirmed the CDCE principles, establishing their central place in Iberoamerican relations. More specifically, the charter made an explicit reference to the CDCE articles 12 (Promotion of international cooperation), 13 (Integration of culture in sustainable development), and 14 (Cooperation for development). Besides, one of the nine principles of the Charter deals with the "specificity of cultural activities, goods and services"stating, "cultural activities, goods and services are bearers of symbolic contents and values that go before and beyond the strictly economic dimension" (IBEROAMERICAN CONFERENCE ON CULTURE, 2006, p. 6).

\section{ASEAN region: multiple visions for one Community?}

\section{Uninformed adhesion, weak civil society and different socializations}

An array of external actors, governments and civil society come together in order to spread the CDCE within the ASEAN region. More specifically, since 2010, the UNESCO officials have aimed to transfer the CDCE in order to encourage information sharing across the ASEAN states and to shape the national policy agendas. Clearly, these officials enjoyed a better understanding of the CDCE and a holistic view of the international tool(NEDERGAARD and DUINA, 2011, p. 181).

First of all, a Framework agreement for Cooperation between UNESCO and ASEAN was signed in 2013 as a result of the ASEAN-UNESCO 
Committee, which has already been established in 2006 for promoting the ASEAN interests within the organization. It was the first cooperation agreement that ASEAN has signed with an UN agency since the ASEAN Charter has come into force in 2008. The promotion of the diversity of cultural expressions is one of the seven priorities areas for cooperation. In this respect, since 2010, UNESCO with the contribution of national governments and external NGOs have organized several meetings (see Table I) in order to encourage more countries to ratify the $\mathrm{CDCE}$ and to familiarize national authorities and culture professionals with the CDCE.

Table I - UNESCO meetings on the Convention on diversity of cultural expressions ${ }^{12}$

\begin{tabular}{|c|c|c|c|}
\hline Date/Place & Scope & Organizer & Participants \\
\hline $\begin{array}{l}\text { June } 2010 \text {, Jakarta, } \\
\text { Indonesia }\end{array}$ & Two-day workshop & $\begin{array}{l}\text { Humanist Institute } \\
\text { for Cooperation with } \\
\text { Developing Countries }\end{array}$ & $\begin{array}{l}30 \text { participants from } \\
\text { civil society and } \\
\text { representatives from } \\
\text { UNESCO offices in } \\
\text { Jakarta and in Bangkok }\end{array}$ \\
\hline $\begin{array}{l}19 \text { October } 2010, \\
\text { Phnom Penh, } \\
\text { Cambodia }\end{array}$ & National workshop & $\begin{array}{l}\text { UNESCO and } \\
\text { Cambodian Ministry of } \\
\text { Culture and Fine Arts }\end{array}$ & $\begin{array}{l}\text { Government institutions, } \\
\text { NGOs and private sector }\end{array}$ \\
\hline $\begin{array}{l}\text { 20-2 I October } \\
\text { 201 I, Phnom } \\
\text { Penh, Cambodia }\end{array}$ & $\begin{array}{l}\text { Two-day Southeast } \\
\text { Asia Expert meeting }\end{array}$ & $\begin{array}{l}\text { UNESCO and } \\
\text { Cambodian Ministry } \\
\text { of Culture and Fine } \\
\text { Arts }\end{array}$ & $\begin{array}{l}30 \text { representatives from } \\
\text { six ASEAN states - } \\
\text { Cambodia, Indonesia, } \\
\text { Malaysia, Philippines, } \\
\text { Singapore, Vietnam -, } \\
\text { Timor-Leste and France }\end{array}$ \\
\hline $\begin{array}{l}\text { 13-15 March } 2012 \text {, } \\
\text { Vientiane, Laos }\end{array}$ & $\begin{array}{l}\text { Three-day workshop } \\
\text { on cultural industries } \\
\text { and the CDCE }\end{array}$ & $\begin{array}{l}\text { UNESCO Bangkok } \\
\text { office }\end{array}$ & Culture professionals \\
\hline & Cultural Diversity & $\begin{array}{l}\text { Ministry of Cultural } \\
\text { Affairs of the }\end{array}$ & $\begin{array}{l}33 \text { countries of the } \\
\text { region, including all the }\end{array}$ \\
\hline $\begin{array}{l}\text { 9-1 I May } 2012 \text {, } \\
\text { Dhaka, Bangladesh }\end{array}$ & $\begin{array}{l}\text { Ministerial Forum } \\
\text { Meeting of the Asia- } \\
\text { Pacific Region }\end{array}$ & $\begin{array}{l}\text { Governmentof the } \\
\text { People's Republic } \\
\text { of Bangladesh and } \\
\text { UNESCO }\end{array}$ & $\begin{array}{l}\text { ASEAN states. The Forum } \\
\text { adopted the 'Dhaka } \\
\text { Declaration' on Cultural } \\
\text { Diversity }\end{array}$ \\
\hline
\end{tabular}

12 The workshop was held in the framework of the Creative Industry Support Programme, funded by the UN-Spain Millennium Development Goals Achievement Fund with the contributions of four UN agencies. 


\begin{tabular}{|c|c|c|c|}
\hline Date/Place & Scope & Organizer & Participants \\
\hline $\begin{array}{l}\text { 4-6 March } 2014, \\
\text { Bangkok, Thailand }\end{array}$ & $\begin{array}{l}\text { Three-day workshop } \\
\text { of focal points for } \\
\text { CDCE in the Asia- } \\
\text { Pacific region }\end{array}$ & $\begin{array}{l}\text { UNESCO } \\
\text { Bangkok office } \\
\text { and International } \\
\text { Federation of Arts } \\
\text { and Culture Council } \\
\text { Association }\end{array}$ & $\begin{array}{l}9 \text { Parties to the CDCE } \\
\text { in the region, as well as } \\
\text { Danielle Cliche, UNESCO } \\
\text { Secretary of the CDCE } \\
\text { and the focal point for } \\
\text { Brazil, Giselle Dupin }\end{array}$ \\
\hline $\begin{array}{l}17 \text { February } 2016 \text {, } \\
\text { Hanoi, Vietnam }\end{array}$ & $\begin{array}{l}\text { Training workshop } \\
\text { on the International } \\
\text { Fund for Cultural } \\
\text { Diversity }\end{array}$ & $\begin{array}{l}\text { UNESCO and Goethe } \\
\text { Institute }\end{array}$ & Culture professionals \\
\hline $\begin{array}{l}\text { 24-25 February } \\
2016 \text {, Thalat, Laos }\end{array}$ & $\begin{array}{l}\text { Training workshop } \\
\text { on the International } \\
\text { Fund for Cultural } \\
\text { Diversity }\end{array}$ & $\begin{array}{l}\text { UNESCO Bangkok } \\
\text { office }\end{array}$ & Culture professionals \\
\hline
\end{tabular}

It's worth noting that the majority of the UNESCO activities were takenfollowing the conclusions of a report on CDCE's effects on the ASEAN region. The report affirmed the apparent failure of the CDCE, the limited socialization of national officials and their poor knowledge regarding the CDCE.

\begin{abstract}
"Among 80 interviewees, only 10 had previously heard of the 2005 Convention. The most informed individuals were from the Ministries of Culture (Indonesia, Vietnam, Cambodia and Thailand), due to their involvement in previous consultative meetings (...) most individuals show a real sense of confusion about the practical dimension of the Convention and have doubts about the appropriate strategies to carry out in their country" (UNESCO, 201 I, p. 6).
\end{abstract}

Clearly, the UNESCO strategies have been established as a response to the poor effects of the CDCE in the region. The three countries, which ratified the CDCE in 2007, had insufficient information about its normative framework, on one side, and on the other, their economic, social, political and ideological contexts were not appropriate for norm transferring. In this view, the process of CDCE diffusion and implementation is neither linear nor straightforward (CARPENTER, 2012). The CDCE implementation in ASEAN region andUNESCO strategies highlight not only an uninformed adhesion to the CDCE, but also an inappropriate context for the $\mathrm{CDCE}$ 
implementation (DOLOWITZ and MARSH, 2000, p. 17). In other words, there is a gap between what has been agreed upon at the intergovernmental level and "what is in fact applied or in force in practice" (GARDINI, 2011, p. 684).

Most importantly,UNESCO officials did not play a role in disseminating the CDCE throughout the period 2003-2009. In short, what is of interest here is how to explain the CDCE ratification by Vietnam, Laos, and Cambodia. A key factor for understanding commitment to CDCE may be the participation of the officials of the three countries to the activities of the OIF and to the pressure exerted by the CDCEentrepreneurs ${ }^{13}$. On one hand, the OIF wasthe first international organization to adopt in 1999 in Moncton, Canada a resolution on the necessity of an international instrument on cultural diversity. Since then, under the instigation of France, Canada and Quebec, the CDCE has been a key component of OIF's policy agenda. On the other hand, the OIF, with the collaboration of officials from Canada, France and Quebec, organized a number of meetings devoted to the diversity of cultural expressions:the regional seminar on cultural diversity in Hanoi, Vietnam in September 2003; the regional seminar on 'cultural diversity, cultural industries and globalization' in Siem Reap, Cambodia in December 2008; the conference on the $10^{\text {th }}$ anniversary of the CDCE in Hanoi, Vietnam, in November 2015. The list of meetings is much longer, but it suffices to make the point that the CDCE was a mobilizing element.

Besides, it's worth bringing in here the societal factor and noting that the commitment to CDCE remains the outcome ofgovernmental decision and the influence of societal groups is only marginal (KROME, 2011).No oneCoalition for Cultural Diversity is established in the ASEAN region andthe culture professional organizations of ASEAN states developed no links with the movement of Coalitions for Cultural Diversity. The only attempt for creating bridgesbetween the International Federation of Coalitions and

13 According to Martha Finnemore and Kathryn Sikkink, norm entrepreneurs 'are critical for norm emergence because they call attention to issues or even 'create' issues by using language, that names, interprets, and dramatizes them. The construction of cognitive frames is an essential component of norm entrepreneurs' political strategies, since, when they are successful, the new frames resonate with broader public understandings and are adopted as new ways of talking about and understanding issues. In constructing their frames, norm entrepreneurs face firmly embedded alternative norms and frames that create alternative perceptions of both appropriateness and interest' (FINNEMORE and SIKKINK, 1998, p. 897) 
the culture professionals of the region took place during the Committee of the Confederation of Societies of Authors and Composers for the Asia-Pacific region in April 2006. In this context, a presentation on the CDCE has made by the French Coalition. As the newsletter of Coalitions pointed out, the participants were not necessarily interested in the development of cultural policies.

Lastly, the promotion of the CDCE could eventually take place through other platforms, such as the ministerial meetings for culture ASEAN-China, Japan, South Korea $(10+3)$ and ASEAN-China $(10+1)$. Rather, throughout the period 2003-2015 the statements of the meetings made no mention to the CDCE.

\section{The diversity of cultural expressions facing competing ideas}

The 2003 ASEAN Summit established as a main priority the creation of an ASEAN Community resting on three pillars: ASEAN PoliticalSecurity Community, the ASEAN Economic Community and the ASEAN Socio-cultural community (ASC). In 2007, ASEAN's leaders approved a "Roadmap for the ASEAN Community" consisting of a "Blueprint" for each of the three communities (BASU DAS et al., 2013, p. 5) that are still far from complete $^{14}$. Soon after, in the $19^{\text {th }}$ ASEAN Summit held in Bali, Indonesia, in November 2011, the ministers responsible for Culture and Arts signed the Declaration on 'ASEAN Unity in Cultural Diversity: towards strengthening ASEAN community'. Yet, it's revealing that even though the ASEAN states made the "promotion of cultural creativity and industry" (ASEAN, 2009, p. 89) a goal for building an ASEAN community, the 2011 Declaration and the ASC Blueprint made no mention to the CDCE.

Another key factor for understanding the CDCE influencein the ASEAN regionshall be the competing ideas that external actors and ASEAN states have disseminated in relation to cultural policies. In this respect, the concept of 'creative industries' founded greater acceptance than the CDCE in Singapore, Thailand and to a lesser extent in Malaysiabecause it fitted more into their economic and political conditions (ACHARYA, 2004, p. 269). Noteworthy is that the concept firstly has been elaborated in Anglo-Saxon countries.It has

14 It's worth noting that the ASEAN way avoids formal institutionalized forms of regional cooperation and highly legal agreements and it includes a preference for informality, consultations and a consensus-based decision-making. Furthermore, South East Asian regionalism is characterized more by 'cooperation' and by agreements, which are largely informal and non-binding in their effects (SÖDERBAUM 2016: 83-85). 
emerged in Australia with the Labour government's 'Creative nation' initiative of 1994 and it was given wider exposure with the election of 'New Labour' in the United Kingdom (UK) in 1997. This strategy established the creative industries as a main component of a 'post-industrial' and knowledge-based economy.It sees the creative economy as a contributor to wealth creation and employment growth, giving a potential to diversify the economies of developing countries and going beyond the traditional ideas of the subsidized arts (FLEW and CUNNINGHAM, 2010, p. 113). In this view, the United Nations Conference on Trade and Development (UNCTAD) prepared two reports on Creative Economy, published in 2008 and 2010,challenging notably the UNESCO monopoly on cultural affairs within the UN system. Besides, the creative economy policy strategy was manifested in initiatives of several governments from the Asia-Pacific region, such as Hong-Kong and South Korea. The idea has been so successful that UNESCO took the lead of preparing the third edition of the report, published in 2013.

On one hand, the Thai Government has promoted the concept of the 'Creative Economy' as critical to Thailand's development. The objective was to establish Thailand as the creative industrial hub of ASEAN. On its turn, Kittirat Na-Ranong, Former Deputy Prime Minister of Thailand, explicitly stressed that

\footnotetext{
"for the South-East Asian region as a whole, the establishment of the ASEAN Economic Community will help facilitate the development of the creative economy. Creative industries that combine ASEAN's rich cultural heritage with the creative inputs and innovations of today will add substantial value. Thailand has cooperated closely with the UN system on promoting the creative economy and has adopted it as one of six key pillars of cooperation under the Thai-UN partnership framework"(UNESCO, 2013, p.74).
}

In this view, the creative sector was a key priority of the Tenth National Economic and Social Development Plan and the Thai Government has allocated around 500 million USD to a 'Creative Thailand' Strategy (LAAKSONEN, 2014, p. 26). Besides, UNCTAD became involved in the process for transferring to the national context the results of creative economy report.It carried out - at the invitation of the Thai government- a four-day mission to Bangkok in March 2009 in order to discuss the main findings of the report. UNCTADalso organized a workshop on "Policy Dialogue 
on Creative Economy Thailand" and attended the international conference "Creative Thailand-Facing the Challenges". As a result, Thailand hosted the first International Creative Economy Forum in November 2010, organized by the Ministry of Commerce, UNCTAD, UNDevelopment Program and World Intellectual Property Organization.

On the other hand, Singapore, influenced by the Australian, Hong-Kong and UK strategies, was one of the first countries in Asia to develop a specific strategy on the creative industries. The goal was to establish Singapore as a New Asia Creative Hub.In 1998, the Committee on National Arts Education released a report entitled 'Creative Singapore - A renaissance nation in the knowledge Age' for emphasizing the need for a coherent policy on creative industries, whereas the Ministry of Information and the Arts published the green paper on 'Investing in cultural capital: a new agenda for a creative and connected nation' (HUI, 2007).As Kawasaki pointed out, Singapore could not have won competitions among other global cities if they did not put an effort into the culture and art" (KAWASAKI, 2004, p. 28).

In addition, following the policy actions in Singapore and Thailand, Malaysia has also recognized "Communication, Content and Infrastructure" as one of the 12 new key Economic Areas and in 2011 it has developed National Creative Industry Policy, whereas the Creative Content Association of Malaysia has been established by several associations of the cultural sector. Lastly, Indonesia changed the name from the Ministry of Tourism to Ministry of Tourism and Creative Economy.

Besides, creative industries were identified as an important area of common relevance for Asia-Europe dialogue at the second ASEF Experts' Meeting on Cultural Policy ${ }^{15}$, held in Melbourne, Australia, in 2011. Consequently, the creative economy became the main priority of the following meetings ${ }^{16}$.

15 The Asia-Europe Meeting (ASEM) is an informal process of cooperation bringing together the EU states, the ASEAN states, China, South Korea, Japan, Australia, New Zeeland, Pakistan, India, Kazakhstan, Bangladesh. Mongolia, Russian Federation, Norway, Switzerland, as well as the ASEAN Secretariat and the EU as regional entities. Since 2003, the biennial ASEM Culture Ministers' Meetings have been established. As a result, the Asian-Europe Foundation organized experts' meetings and public forums on cultural policy issues.

$166^{\text {th }}$ ASEF Experts' Meeting and Public Forum Experts on Creative Economy in Asia and Europe: Emerging Pillar of Economic Growth and Development (Hanoi, Vietnam, December 2013); $7^{\text {th }}$ ASEF Public Forum on Creative Industries in Asia and Europe: Enabling Crossovers (Amsterdam, Netherlands, October 2014); $8^{\text {th }}$ ASEF Public 
Finally, the divergent strategies among ASEAN states in the cultural sector could also be illustrated by the fact that in the WTO debate on the trade-culture nexus the ASEAN states are divided without a clear preference if the audiovisual services should be included on the WTO agenda (BOAS, 2002). As a result, four ASEAN states took some commitments in the audiovisual sector: Singapore, Thailand, Malaysia, and Vietnam. In the same vein, during the negotiations on Transpacific PartnershipAgreement, whereas Brunei, Malaysia and Vietnam claimed for an exclusion of cultural services from the agenda of negotiations, Singapore was against the cultural exception (VLASSIS and GAGNE, 2014). Lastly, it should be noted that in August 2005, the ASEAN ministers responsible for Culture and Arts had to deal with the liberalization of trade in the culture sector under the ASEAN framework agreement on services. It's revealing that the awareness related to this topic was poor. The ministers pointed out that this issue was "a relatively new area for ASEAN" and they agreed "that it needed to be discussed further with the ASEAN economic officials and would be kept informed of developments" (ASEAN, 2005).

\section{Concluding remarks}

The ambition of the article was to deal analytically and comparatively with the multidimensional links between international norms and regions. Clearly, the regional governance is an intrinsic part of multilayered global cultural governance on one side, and on the other, exploring both state and nonstate actors and both formal and informal forms of regional action is largely necessary in order to understand the linkage between international norms and regions. Besides, to the initial question of whether international norms and regions are mutually strengthening or regions are forms of resistance, the article acknowledges that linking international norms to regions is a multidimensional process.In this respect, the answer to this question varies depending on the intrinsic features of each region and on several international parameters: the political regimes, the link between national governments and societal groups, the leadership from national governments, the political

Forum on Creative Cities in Asia and Europe (Gwangju, Korea, November 2015); $6^{\text {th }}$ Asia-Europe Culture Ministers' Meeting focused on Creative Industries (Netherlands, October 2014). 
influence from norm entrepreneurs, as well as the common learning from abroad.

On one hand,several ASEAN states do not take the CDCE as a serious and useful normative framework, expressing doubts about its applicability. Clearly, the ASEAN states did not so far reach common agreement on what their position in this issue-area should be.In fact, the governments are strategic actors with different motivations. The lack of ASEAN common position is the result not only of ASEAN's economic and political heterogeneity, but also of policy capacity gap and of different external influences, which led to divergent ambitions regarding the CDCE.My analysis demonstrated that even though Vietnam, Cambodia, Laos ratified the CDCEnotably due to their inclusion in the Francophone networks, they had insufficient understanding of how the CDCE worked and they lacked the capacity necessary to implement policies on this domain (HAFFNER-BURTON and TSUTSUI, 2007). More specifically, capacity-building measures were necessary in the case of Vietnam, Cambodia, Laos, and Indonesia in order to allow them to implement successfully the CDCE. My analysis illustrated not only an uninformed adhesion to the CDCE, but also an inappropriate context for the CDCE implementation. As a result, UNESCO strategies aimed to encourage information and expertise sharing. On their turn, despite their institutional challenges,the four ASEAN states saw the CDCE as a means of strengthening the national policy capacity in cultural affairs. Similarly, they attempted to translate the CDCE into concrete policies, seeking material and technical resources from the CDCE framework to support these policies. Besides, the CDCE mechanisms, such as technical assistance, capacity-building, material incentives and normative persuasion offered several resources to the culture civil society of the ASEAN Parties and platforms for interaction, even very limited, with the national authorities, leading to an increase in dialogue, especially in Vietnam, Cambodia and Indonesia. By contrast, other ASEAN countries, such as Thailand, Singapore or Malaysia, influenced notably by Australia, Hong-Kong and UNCTAD - decided to leave the CDCE off their national agendas in order to prioritize and promote - with the contribution of private sector - the concept of 'creative economy' about which they feel strongly for policy, strategic and normative reasons. In this sense, a greater emphasis on the CDCE and increased opportunities to promote an ASEAN 
convergence is largely dependent on a common socializing from abroad, on the multilateral venues and fora in which the ASEAN national authorities participate, on the importance of leadership from national governments, as well as on the growth and exchanges of a more active civil society.

On the other hand, the Mercosur states are far more receptive to the CDCE than the ASEAN states and in fact, they developed a quite coherent external position on this issue-area. Moreover, they became very involved to the CDCE implementation and included the diversity of cultural expressions in the national and regional policy agendas. Besides, the CDCE led Mercosur to increase its actorness in cultural affairs. Clearly, implementing the CDCE in Mercosuris the result of formal agreements made within the treaty, but it is also the result of more informal processes set in motion by the general process of the CDCE dissemination (ASPINWALL, 2011).In the previous sections, I highlighted some of the less formal mechanisms for norm diffusion, including pressure from civil society, informal interaction among government's officials and the involvement of academic milieu. First, the activities of Mercosur culture organizations of professionals go from political pressure to information sharing and they developed strong links with the transnational network for the diversity of cultural expressions. They became, hence, a partner and legitimator (SÖDERBAUM, 2016, p. 137-140) of the CDCE implementation in Mercosur region. An equally important factor is the common socialisation of national officials and deputies of Mercosur states and their integration in regional meetings and forums, through which the CDCE was disseminated. These meetings helped the national officials learn more about the CDCE content. To this picture it should be added the dynamic advocacy of CDCE entrepreneurs, such as Canada and Quebec in these regional networks. Finally, another factor is the smooth, technical-level communication and information sharing among culture ministries in the Mercosur states. In other terms, bureaucrats, NGOs and others communicate directly across the Mercosur borders and within the Inter-American region. All these factors contributed to the building of a common position among Mercosur states vis-à-vis the issue of the diversity of cultural expressions, to the inclusion of the CDCE in their policy agendas and to the dynamic implementation of the latter. 


\section{Acknowledgements}

I am grateful to Sebastian Santander, Chrysoula Lentzou, Luis Albornoz, as well as to the anonymous reviewers for their valuable comments on previous versions. An earlier version of this article was presented at the ISA (International Studies Association) Asia-Pacific Conference, Hong Kong, 25 to 27 June 2016 at the panel 'Norms and Regional Organizations in the AsiaPacific'. Any omissions or errors obviouslyremain entirely my own.

\section{References}

ACHARYA, A. How Ideas Spread: Whose Norms Matter? Norm Localization and Institutional Change in Asian Regionalism. International Organization, v. 58, n. 2, p. 239-275, 2004.

ALBORNOZ, L. The International Fund for Cultural Diversity: a new tool for cooperation in the audiovisual field. International Journal of Cultural Policy, February, Eprint, DOI: 10.1080/10286632.2015.1008467, 2015.

ASEAN. Roadmap for an ASEAN Community 2009-2015. Jakarta: ASEAN Secretariat, 2009.

ASEAN. Chairperson's Press Statement of the Second Meeting of the ASEAN ministers responsible for Culture and Arts (AMCA) and the AMCA Plus Three Bangkok, 3 August 2005.

ASPINWALL, M. Consequences of regionalism: the politics of North American trade. In: WARLEIGH-LACK A., ROBINSON N., ROSAMONDB., eds. New regionalism and the European Union: dialogues, comparisons and new research directions, London: Routledge, p. 158-173, 2011.

AVANT D., FINNEMORE, M. and SELL, S.K., eds. Who Governs the Globe? Cambridge: Cambridge University Press, 2010.

BASU DAS, S. et al. The ASEAN Economic Community: a work in progress. Singapore: Institute of Southeast Asian Studies, 2013.

BOAS, M. The trade-environment nexus and the potential of regional trade institutions. In: BRESLIN S. et al., New regionalism in the Global political economy, London: Routledge, p. $48-65,2002$.

BÖRZEL, T.A. Why you don't always get what you want: EU enlargement and civil society in Central and Eastern Europe. Acta Politica, v. 45, n. 1-2, p. 1-10, 2010. 
Linking International Norms to Regions: Mercosur and ASEAN facing the challenge of cultural diversity | Antonios Vlassis

BOUCHER, C. Follow up report on Hemispheric Implementation of the Convention on the Protection and Promotion of the Diversity of Cultural Expressions and International Trade Negotiations. $7^{\text {th }}$ General Assembly of the Parliamentary Confederation of the Americas (COPA), Quito, Ecuador, May 2006.

BURRI, M. The UNESCO Convention on Cultural Diversity: an appraisal five years after its entry into force. International Journal of Cultural Property, v. 20, p. 357-380, 2014.

CARPENTER, C. R. Governing the global agenda: 'gatekeepers' and 'issue adoption' in transnational advocacy networks. In: AVANT D., FINNEMORE M. and SELL S.K.eds. Who Governs the Globe? Cambridge: Cambridge University Press, p. 202-237, 2012.

DE BEUKELAER, C., PYYKKÖNEN M., SINGHJ. P. eds. Globalization, Culture, and Development. New York: Palgrave MacMillan, 2015.

DOLOWITZ, D. P. and MARSHD. Learning from Abroad: the Role of Policy Transfer in Contemporary Policy-Making. International Journal of Policy and Administration, v. 13, n. 1, January, p. 5-24, 2000.

EUROPEAN UNION-LATIN AMERICA-CARAIBES. Declaration of Vienna-Fourth EU-LAC Summit. Vienna, Austria, 12 May 2006.

FINNEMORE, M. and SIKKINK K. International Norm Dymanics and Political Change. International Organization, vol. 52, n 4, p. 887-917, 1998.

FLEW, T. and CUNNINGHAM, S. Creative industries after the First Decade of Debate. The Information Society, v. 26, n. 2, p. 113-123, 2010.

GAGNE, G. The Trade and Culture Debate: Evidence from US Trade Agreements. New York: Lexington Books, 2016.

GARDINI, G. L. Mercosur: What you see is not (always) what you get. European Law Journal, v. 17, n. 5, p. 683-700, 2011.

HAFNER-BURTON, E. and TSUTSUI, K. Justice Lost! The Failure of International Human Rights Law to Matter Where Needed Most. Journal of Peace Research, v. 44, n. 4, p. 407-425, 2007.

HUI,D. The creative industries and entrepreneurship in East and Southeast Asia. In: HENRY C. ed. Entrepreneurship in the Creative Industries: An international perspective, Northampton: Edward Elgar, p. 9-29, 2007. 
IBEROAMERICAN CONFERENCE ON CULTURE. Iberoamerican Cultural Charter. Montevideo, 13-14 July 2006.

LAAKSONEN, A. Analytical Report: Cultural Policies and the 2005 UNESCO Convention in Asia. Sydney: International Federation of Arts Councils and Culture Agencies, 2014.

LOISEN, J. and DE VILLE, F. The EU-Korea Protocol on Cultural Cooperation: Toward Cultural Diversity or Cultural Deficit? International Journal of Communication, n. 5 , p. 254-271, 2011.

KATZENSTEIN, P. J. A world of regions: Asia and Europe in the American Imperium. Ithaca: Cornell University Press, 2005.

KAWASAKI, K. Cultural Hegemony of Singapore among ASEAN Countries: Globalization and Cultural Policy. International Journal of Sociology, v. 13, p. 22-35, 2004.

KROME, C. ASEAN and civil society: an incompatible relationship? In: BÖRZEL T. A. et al. Roads to Regionalism: Genesis, Design, and Effects of Regional Organizations. Surrey: Ashgate, 2012.

KOZYMKA, I. The Diplomacy of Culture. The Role of UNESCO in Sustaining Cultural Diversity. London: Palgrave Macmillan, 2014.

MALAMUD, A. and SCMITTER P. C. The experience of European integration and the potential for integration in South America. In: WARLEIGH-LACK A., ROBINSON N., ROSAMONDB. eds. New regionalism and the European Union: dialogues, comparisons and new research directions, London: Routledge, p. 133-157, 2011.

NEDERGAARD, P. and DUINA F. The OMC in comparative perspective: learning and community-building in the OECD and Nordic Council of Ministers. In: WARLEIGHLACK A., ROBINSON N., ROSAMONDB. eds. New regionalism and the European Union: dialogues, comparisons and new research directions, London: Routledge, p. 177-200, 2011.

NESADURAI, H. The Global Politics of Regionalism: Asia and the Asia-Pacific. In: FARRELL, M. et al., Global Politics of Regionalism: Theory and Practice. London: Pluto Press, p. 155-170, 2005.

NEUWIRTH, RJ. The Future of the Culture and Trade Debate: A Legal Outlook. Journal of World Trade, v. 47, p. 391-420, 2011.

ORGANISATION OF AMERICAN STATES. Declaration and Plan of Action of Cartagena de Indias. 13 July, 2002. 
Linking International Norms to Regions: Mercosur and ASEAN facing the challenge of cultural diversity | Antonios Vlassis

RICHIERI HANANIA, L. ed. Cultural diversity in international law: Effectiveness and normativity of the 2005 Convention on diversity of cultural expressions. London: Routledge, 2014.

SANTANDER, S. Variances and ruptures dans le Mercosur. In:SANTANDER S. ed.Relations internationales et régionalisme. Dynamiques internes et projections nationales. Liège, Presses universitaires de Liège, p. 11-32, 2012.

SASAKI, S. Art Culture creativity in Southeast Asia: Perceptions on the 2005 Convention on the Protection and the Promotion of the Diversity of Cultural Expressions. UNESCO Bangkok office, 2011.

SHI, J.Free Trade and Cultural Diversity in International Law, Oxford and Portland, Hart Publishing, 2013.

SÖDERBAUM, F. Rethinking Regionalism. London: Palgrave Macmillan, 2016.

UNESCO. Creative Economy Report 2013 Special Edition. Paris: UNESCO, 2013.

UNESCO. Strengthening the governance of culture to unlock development opportunities: results of the UNESCO-EU expert facility project. Paris: UNESCO, 2013.

UNESCO. Avant projet de Convention sur la protection de la diversité des contenus culturels et des expressions artistiques: Partie II Commentaires spécifiques des États membres. CLT/CPD/2004/CONF.607/1, Paris: UNESCO, 2004.

VLASSIS, A. European Commission, trade agreements, and diversity of cultural expressions: between autonomy and influence. European Journal of Communication, v. 31, n. 4, p. 446-461, 2016a.

VLASSIS, A. Organizaciones regionales y diversidad cultural: la diplomacia de la Unión Europea con el Mercosur entre la sombra de Hollywood y la acción intergubernamental. Cuadernos de Información y Comunicación, v. 21, p. 97-115, 2016b.

VLASSIS, A. Gouvernance mondiale et culture: de l'exception à la diversité. Liège: Presses universitaires de Liège, 2015a.

VLASSIS, A. Culture in the post-2015 development agenda: the anatomy of an international mobilisation. Third World Quarterly, v. 36, n. 9, p. 1649-1662, 2015 b.

VLASSIS, A. L'UNESCO face à l'enjeu "commerce-culture": quelle action politique pour une organisation internationale? Politique et sociétés, v. 32, n. 3, p. 81-101, 2013. 
VLASSIS, A. La mise en ouvre de la Convention sur la diversité des expressions culturelles: portée et enjeux de l'interface 'commerce-culture'. Études internationales, v. 42, n. 4, p. 493-510, 2011.

VLASSIS, A. and GAGNE, G. Partenariat transpacifique et exception culturelle: rapports de force. Culture, commerce et numérique, v. 9, n. 1, February, 2014.

\section{Conectando Normas Internacionais às Regiões: Mercosul e Asean frente o desafio da diversidade cultural}

\section{Resumo}

A Convenção sobre Diversidade de Expressões Culturais (CDCE), adotada pela UNESCO em 2005, tornou-se um dos principais mecanismos dentro da multifacetada governança global das indústrias culturais, estabelecendo novas práticas no setor cultural. O artigo defende uma visão original sobre difusão e implementação de normas, com foco em duas regiões: Mercosul (Mercado Comum do Sul) e ASEAN (Associação das Nações do Sudeste Asiático). Através da análise da transferência da CDCE de nível internacional para as regiões do Mercosul e da ASEAN, o artigo procura explorar quatro questões-chave: por que os atores se envolvem na mudança de normas? Quem são os principais atores no processo de transferência de normas? O que é transferido e por quê? O que restringe ou facilita o processo de transferência de normas?

Palavras-chave: difusão de normas, regiões, Mercosul, ASEAN, UNESCO, organizações nãogovernamentais, indústrias culturais, diversidade cultural. 